\title{
Introductory parts to the constitutions of Visegrad Group countries. Their relevance, constitutional identity and relation towards European Constitutional Identity.
}

\author{
Mgr. Karol POPŁAWSKI
}

\begin{abstract}
Postponed article seeks to find an answer on legal meaning and role played by introductory parts of the Constitutions of Visegrad Group (Hungary, Czech Republic, Republic of Slovakia and Republic of Poland) countries - both in internal and external (European) aspect. They commonly expresses respect to freedom and human dignity and vast catalogue of principles and values known in European legal discourse. Preambles though are also main source of reconstructing national identity and constitutional identity and thus makes it worth referring to. Regional Constitutional Courts concerned preambles in their judgment several times and scope of their activities as well as methods are worth interpreting. Relation to international principles and values is also not a coincidence, as it is connected with the process of democratic transition in post - communism countries. Hence it refers to notions of constitutional identity and certain level of "openness" of Constitutions of the V4 countries on European law.
\end{abstract}

\section{Keywords}

preambles, introductory parts to the constitution, Visegrad Group countries, national identity, constitutional identity

\section{Introduction}

On 1989 countries of Central and Eastern Europe entered the path of a democratization. In regional countries it related to similar or even identical circumstances: crisis of autoritharian power, breakdown of the political system, appointment of the new government, introducement and establishment of democracy, appointment of the democracy power and new political (democratic) actors. ${ }^{1}$ Parallely began process of "institutional and ideological

1 KUBAS, Sebastian: Dynamika procesu demokratyzacji Węgier. Próba określenia zjawiska w teorii [Dynamic of the democratisation process in Hungary. Assignement in theory], in: 25 lat transformacji w krajach Europy Środkowej i Wschodniej, BARAŃSKI, Marek - WIŚNIEWSKI, Jerzy (eds.), Katowice 2014, 89. 
integration with the West," 2 which ended with huge accession into the European Union in 2004. Below article is objectively limited to the Visegrad Group countries, however conclusions (at least on the legal relevance of the constitutional preambles) can be assigned to each Central and East European country, which was under Soviet Union influence.

Western legal doctrine is sometimes indicating that mentioned transition could be seen as "massive transfers of material resources, know-how, political and economical model from the West to the East Europe". ${ }^{3}$ Even first glance implies whole process to be one directional - from so called "old democracies" to "new democracies". Hence, it was better and more politically correct to determine that "Eastern countries have aspired to fill the empty space created by the breakdown of the communist system", but - from the beginning of post - communism transitional period - aimed on 'returning to Europe and its standards'. ${ }^{4}$ Standards were thought to be common, but disturbed and distorted by communism regime. Fundamental for the European Union was though a belief on unity of principles and values characteristic to modern, democratic countries. Eventually it led to the conclusion on European common constitutional heritage, shared by countries of Europe. It also encompassed clear conviction that Central and Eastern European Countries share those principles and values, which needed only to be reinstated after the communism period. ${ }^{5}$

On that basis, principle of sovereignty came into the fore. It was both dimensional: as sovereignty and independence of the State as well as sovereignty of Nation. Recently regained sovereignty again was about to be challenged - now by the European entities (especially the European Union; hereinafter EU), with its principles of priority and direct application of EU's law. ${ }^{6}$ Legal and political environment needed though a proper balance between European and National Identity, which was initially presented during works on the Treaty of Maastricht.7 Now - on the basis of the art. 4 par. 2 of the so-called "Lisbon

2 GARLICKI, Lech: Constitutional Court of Poland 1982-2009, in: The political origins of Constitutional Courts. Italy, Germany, France, Poland, Canada, United Kingdom, PASQUINO, Pascquale - BILLI, Francesca (eds.), Rome $2009,30$.

3 ERIKSEN, Svein: Institution building in Central and Eastern Europe: Foreign Influences and Domestic Responses, in: Review of Central and East European Law, 32, 2007, 3, 333.

4 Ibidem, 334.

5 BARTOLE, Sergio: Comparative Constitutional Law - an Indispensable Tool for the Creation of Transnational Law, in: European Constitutional Law Review, 13, 2017, 4, 601-602. Huge differences concerning legal culture extorted real and advanced participation of monitoring and advisory bodies (especially Venice Commission and Organisation for Security and Co-operation in Europe. They were scrutinizing whole process, maintaining permanent advisory activities in which were establishing modern democratic standards, which ought to be achieved. See: JOWEL, Jeffrey: The Venice Commission: disseminating democracy through law, in: Public Law, 2001, $675-676$.

6 Interestingly on that aspect in English: TATHAM, Allan: Central European Constitutional Courts in the Face of EU Membership. The influence on the German model in Hungary and Poland, Leiden 2013, 210-218. Among Polish authors: BANASZAK, Bogusław: Limitation of Sovereignty by the European Integration - The Polish Approach, in: lus Gentium: Comparative Perspectives on Law and Justice, Dordrecht 2016, 102. GARLICKI, Lech: Constitutional Law, in: Introduction to Polish Law, FRANKOWSKI, Stanisław (ed.), Hague 2005, 5-8.

7 Treaty on European Union on 29 July 1992, Official Journal of the European Communities, C 191, vol. 35, 29 July 1992, 1-110. Need of ascertaining European Identity on the international scene was pointed in art. B of the Maastricht Treaty, but direct respect to National Identities of the Member States resulted from art. F, but it was conditional - if only system of government of the Member States is founded on the principles of democracy. Preceding motives were mentioned in the preamble of the Treaty, where Member States (alongside many other fundamental principles and values f.e. of free market) emhasized importance of "the ending of the division of European continent and the need to create firm bases for the construction of the future Europe". It was also desired to deepen solidarity between people of Europe - while respecting their history, culture and their traditions. 
Treaty" ${ }^{\prime 8}$ - national identity is presented as an obligation to "respect the equality of Member States before the Treaties as well as their national identities, inherent in their fundamental structures, political and constitutional, inclusive of regional and local self-government. It shall respect their essential State functions, including ensuring the territorial integrity of the State, maintaining law and order and safeguarding national security. In particular, national security remains the sole responsibility of each Member State". In parallel, we should also emphasize the concept of constitutional identity.

Particularly notions of national identity and constitutional identity were used in the same contexts and meaning, which shall be treated as incorrect. Simplifying, national identity being itself a principle of EU law, is based on a "liberal concept for the respectful treatment of the members of a multinational political community" whereas constitutional identity is about exercising several principles of the constitutions of the EU Member States, fundamental for the sovereignty concept. ${ }^{9}$ It does not mean a priori accept to primacy of internal legal orders and is rather pragmatic vision of different actors of international legal discourse interested in protecting their sovereignty. Bearing in mind circumstances of the transformation period, shall be emphasized that abovementioned process needed time and at the same time did not give such time. Legal unification was though one thing, but completely different was opening societies on pending changes. Described period for countries of Central and Eastern Europe was sometimes called "perfect for constitutional engineering". Thus important was guaranteeing proper understanding of the whole process and such role - inevitably - had to be played by the introductory parts to the constitutions. It is however dominant theory, that preambles are the easiest way to proclaim principles and values particulary important from "past and present" of the countries. ${ }^{10}$ Hence it plays crucial, system-building role by balancing relations between values. By explicit reference to the history of the country and its legal system, introductory parts to the constitutions of post-communism countries also includes "rejection of the previous communist system". ${ }^{11}$ Then it leads to complex and demanded process of establishing new - free and democratic - national identity.

\section{Subject of considerations}

Articles refers to the countries of Central Europe, which are situated in the scope of Visegrad Group (Czechia, Hungary, Poland and Slovakia). Analysis will be sharpened to the in-

8 Consolidated versions of Treaty on European Union and the Treaty on the functioning of the European Union, Official Journal of the European Union, C 202, vol. 59, 7 June 2016, 1-388. Concept of the National Identity was significantly deepened, however Preamble to the mentioned Treaty sustained in similar form. Worth attention is a concept of the EU, which is "drawing inspiration from the cultural, religious and humanist inheritance of Europe", which is basis of inviolable and inalienable rights of the human person, freedom, democracy, equality and the rule of law.

9 CLOOTS, Elke: National Identity, Constitutional Identity, and Sovereignty in the EU, in: Netherland Journal of Legal Philosophy, 45, 2016, 2, 82-84.

10 GARLICKI, Lech: Wstęp [Introduction], in: Konstytucja Rzeczypospolitej Polskiej. Komentarz. Tom V [Constitution of the Republic of Poland. Commentary. Vol. V], GARLICKI, Lech (ed.), Warszawa [Warsaw] 2007, 2.

11 GWIŻDŻ, Andrzej: Wstęp do Konstytucji - zagadnienia prawne [Introduction to the Constitution - legal aspects], in: Charakter i struktura norm Konstytucji [Character and structure of the norms of the Constitution], TRZCIŃSKI, Janusz (ed.), Warszawa [Warsaw] 1997, 169. 
troductory parts to the constitutions of Czechia, Hungary, Poland and Slovakia in the way they refer to the issue of the national and constitutional identity. ${ }^{12}$ That significantly limits scope of considerations, but answers the need of sustaining methodological correctness. As Konrad Zweigert pointed, one of the main faults in comparative studies is not having certain scope of research and lack of conclusions. ${ }^{13}$ They are made in the end of the article. Furthermore, mentioned countries share similar transitional experiences and were following the same path of integration with the EU. Noticeably they recent history refer to common traumatic experiences connected with breaching human rights and rule of law in post communist countries. Obviously author sees the fact that ascertaining similar history of V4 countries could be accepted only superficially. General factors - which we divide on external and internal - were rather similar, but intensity and model of transformation (also the intellectual one) were different. ${ }^{14}$ In Hungary transformation was initiaded by higher (intelligentsia - scientist) social group and in middle 50s (20 ${ }^{\text {th }}$ century) Hungary created rather liberal form of communism regime. ${ }^{15}$ In Poland transformation process was inspired by the working class. In parallel, abovementioned countries had to create legal system from the beginning, which was sometimes seen as "recalling rudiments of law". ${ }^{16}$ Passing time urged Czechia to create - except strict constitutional act - also a Charter of Fundamental Rights of the Czech Republic. Czech authors states such distinction aimed on recreating commonly broken rights and freedoms as soon as possible. ${ }^{17}$ It can be assumed, the level of breaching fundamental human rights and aspiration of the society to live in a free and democratic country were the main factors of transformation. Basically, it was similar in Slovakia, although there was no need for dividing a constitution or a charter of rights. However, attention is drawn to the common aspiration of these countries to adopt the principles and ideas of Western liberal democracies. ${ }^{18}$ According to the reconstruction of the system of legal guarantees for the protection of the lawful system - preambles express also the need to rebuild the economic system, and, subsequently, to build a common identity of the whole, sometimes divided society. ${ }^{19}$

12 According to terminological differences (especially concerning Hungary) it should be better - in order to maintain correct terminology - to say not about preambles, but introductory parts of the constitutions. However, I will use those terms interchangeably.

13 DE CRUZ, Peter: Comparative law in a Changing World, New York 2007, 8.

14 KUBAS, 92. As an external factors, author presents especially political changes in USA and Soviet Union (election of R. Regan for President of the USA, election of M. Gorbachev on General Secretary of Soviet Union), which - as a result - weakened the Soviet Union. According that, recent elits of "satelite states" had to change methods of governing the country. That lead to an internal factor, which was: disappointment of vast social groups as well as economical difficulties - resulting with strengthening the opposition.

15 Ibidem, 92-95.

16 BAŁABAN, Andrzej: Polskie problemy ustrojowe. Konstytucja, źródła prawa, samorząd terytorialny, prawa człowieka [Polish political system dilemmas. Constitution, sources of law, local government, human rights], Kraków [Cracow] 2003, 42.

17 KUDRNA, Jan: Two Preambles in the Czech Constitutional System, in: Acta Juridica Hungarica, 52, 2011, 1, 24. Despite that, such solution created also the possibility to solemn proclamation of the meaning of human rights and its protection in Czech constitutionalism.

18 KINANDER, Morten: Comparing Courts: The Accountability Function of the Constitutional Courts of Poland and Hungary, in: Review of Central and East European Law, 39, 2014, 2, 153.

19 MŁYNARSKA-SOBACZEWSKA, Anna: Normatywizacja pamięci zbiorowej w preambułach do konstytucji państw postkomunistycznych, in: Przegląd Prawa Konstytucyjnego, 18, 2014, 2, 239. 
Introductory parts to the constitutions of Visegrad countries possess a specific, unique character, which enables them to play different roles in a theory of law and whole legal discourse. Analysis also has to be complex and include many factors. Recreation of the legal system from the ideologically oriented communist law, balance between past and upcoming future, level of an inspiration from historical experiences and also integration with Europe - main principles and values emerging from that process, forces the researchers to maintain deepened studies. ${ }^{20}$ As it was once stated, "monocausal explanations [...] that focuses exclusively on: political and legal culture, institutional design or actor-based behavior" shall be a subject of criticism. ${ }^{21}$ Obviously complete, methodological correctness - from legal and social point of view - is reaching far beyond of the form of typical scientific article. That is why the analysis is concerned on the introductory parts as part of legal text partially answering all of above issues. Mainly I will focus on the way it has been used to determine national and constitutional identity, which reflected process of integration with the EU, including reflection on the legal relevance of the introductory parts to the constitution. In author's opinion such scientific approach will help to maintain methodological correctness, as the main factors of the process were almost identical for each of analyzed country. Potential, internal differences in attitude towards integration process as well as historical approach, would make the research more valuable.

\section{What exactly are the preambles?}

Preambles are significantly specific, but immanent part of legal text. ${ }^{22}$ They are situated in the beginning of the legal text, usually after the title. On that basis, one can assume its legally binding character (which though can not be interpreted as complete legal relevance)..$^{23}$ It would be mistaken to identify preambles only as content of the constitutions, however they are used mainly in basic laws. Liav Orgad - an author of fundamental work on the introductory parts to the constitutions - stated the preambles shall be rather identified through their content rather than specific location. ${ }^{24}$ In this sense they are sometimes used

20 See: MADEJA, Andrzej: Komparatystyka konstytucyjnoprawna. Antecedencje, ewolucja, przewidywanie kierunku rozwoju [Comparative Constitutional Law. Origins, Evolutions, Possible Development], in: Studia luridica Toruniensia, 6, 2010, 134-141.

21 KINANDER, 150. In fact author made such conclusion comparing practice of Constitutional Courts of Poland and Hungary. He correctly emphasized that even if one factor will be absolutely comparable and correct, rest will probably fail in the context of similarity.

22 KUTLESIC, Vladen: Preambles of Constitutions - a comparative study of 194 current constitutions, online: https://constitutional-change.com/preambles-of-constitutions-a-comparative-study-of-194-current-constitutions/ (Downloaded 1 September 2019). Subject of the analysis is the content of almost every preamble of modern constitutions. It points common features and values, regional similarities and differences between some constitutions (especially of Middle - East European countries and Near East countries). Considering data presented here, only 54 on 194 Constitutions does not contain introduction, which equals about $72 \%$.

23 More on that: BAŁABAN, 42. Author points that preamble occuring after title of legal act (Constitution) prejudges, it is an internal part of such act. Other authors points that preambles are changed in the same proceedings as whole constitution, which makes it immanent part of constitution. E.g.: BISZTYGA, Andrzej: Zmiana Konstytucji jako źródła prawa o najwyższej mocy prawnej [Changing the Constitution as the act of highest legal power], in: Zmena Práva, BÁRÁNY, Eduard (ed.), Bratislava 2013, 90.

24 ORGAD, Liav: The preamble in constitutional interpretation, in: International Journal of Constitutional Law, $8,2010,4,716$. 
(but in limited scope) to creation of "metanorms" - so strictly speaking principles, which creates shape of whole country as well as regulating lower - order laws. ${ }^{25}$ Preambles are written sequentially in solemn language, which is far from the strict criteria of law making. It also reflects on its vague legal relevance. ${ }^{26}$ Hence occurred theory, that preambles - in its form and content - creates risk of using them in "propaganda purposes." 27 Such assumption may be based on clear historical references, typical in the content of preambles. Some scientists proclaim them to be "declaration of independence".${ }^{28}$ Hence we can state, that preambles are created also to ignite certain social changes or attitude. It was obvious even one hundred years ago, during initial negotiations on the preamble to the constitution of the League of Nations. ${ }^{29}$ As it was correctly pointed "few of them 'peoples of the world' will study in detail provisions of the constitution. Many could not understand them in any case (...) These purposes and means should be fully and clearly stated in the preamble, which should be in effect a declaration of principles". However, just as preambles can foster integration by forging a common identity, so also they can be disintegrative, driving people apart and contributing to social tension. ${ }^{30}$

Modern preambles could be found different length and rather similar content, which we can divide into 5 categories. First is the entity of the Sovereign, being in particular "specifying source of sovereignty". Second, usual part of the preambles are the historical narratives. As L. Orgad rightly observed it tells "specific stories that are rooted in language, heritage and traditions. These stories shapes the common identity (we)" ${ }^{31}$ Third are the supreme goals of the state and society. Among them we shall point f.e. human dignity, justice, democracy (at least in European zone), sovereignty of state and nation. Fourth and most interesting from the scope of this analysis is proclamation of national identity. It shall be understood continuously as actual identity typical for certain constitutional system, but also future aspirations (usually established by international organizations). Fifth is a reference to God and religion. ${ }^{32}$ Such conclusions were made upon introductions to the constitutions from the whole world countries. Furthermore, it is worth noticing specific of the constitutional preambles of the Central Europe countries. There are undoubtedly the same inclinations which displays in content of almost every preamble of their constitutions. ${ }^{33}$ Reasons of such regularity is not exactly known. It is sometimes relating to common, traumatic experiences

25 KAMIŃSKI, Antoni - KAMIŃSKI, Bartłomiej: Inżynieria konstytucyjna w postkomunistycznych przemianach ustrojowych [Constitutional engineering in post communism political chages], in: Ruch prawniczy, ekonomiczny i socjologiczny, 78, 2016, 2, 251.

26 BANASZAK, Bogusław: Konstytucja Rzeczypospolitej Polskiej. Komentarz [Constitution of the Republic of Poland. Commentary], Warszawa [Warsaw] 2012, 4.

27 GWIŻDŻ, 169. Cited author presented reserved attitude towards using preambles in the legal discourse, which was probably resulting from instrumental way of treating preambles during communism.

28 Ibidem, 173.

29 See: DAVIS, Charles Hall: Preamble to Constitution of the League of Nations, in: Virginia Law Register, 5, $1919,1,16$.

30 ORGAD, 731.

31 Ibidem, 717.

32 Ibidem, 716-718.

33 MŁYNARSKA-SOBACZEWSKA, 240. Author suggest that practically only exception is introduction to Basic Law of Hungary from 25 April 2011. 
connected with breaching human rights and rule of law in post-communist countries. It is noticed, that protection of recently evolved reality, creates new duties in the system of protecting law, which sometimes "reminds rudiments of law - abidingness". ${ }^{44}$ Pointing typical elements in the content of the introductory parts to the constitutions of V4 countries, we indicate: certain attitude to passed years, a declaration of change in values, all issues related to the rule of law, issues of liberty and human rights. According to the reconstruction of the system of legal guarantees for the protection of the lawful system - preambles express also the need to rebuild the economic system and - what was already mentioned - creation of the national identity.

Here it would be justified to make couple of remarks on the legal relevance of the preambles to the constitutions, but from general perspective. Again, L. Orgad has created typology, which should be treated as correct and binding. Thus, he emphasized the preambles could possess following character: ceremonial - symbolic (being kind of a justification of the whole act - not only instructing, but also persuading), interpretative (as a tool for correct understanding the meaning of the statute, but never prevailing over articulated part of the constitution), substantive (in word, serving independent sources for rights and obligations). ${ }^{35}$ Regional researchers (T. Stawecki) states that constitutional preambles (in the Basic Laws of these states) are not directly applicable and require further substantiation (similary f.e. P. Holländer), by which they presents its interpretative role. ${ }^{36}$ Hence K. Stoichev (judge of the Bulgarian constitutional court) says that introductory parts in general do not have binding juridical character, although expressions referring to democracy and human rights are so-called "interpretation directives". On the other hand, V. Sinkevicius points out that not all standards are possible to be forwarded in an articulated form. He states, therefore, that the preamble does not only express philosophical and political categories, but also legal ones. ${ }^{37}$ Analyzing the countries of the Visegrad Group, it should be admitted that they essentially share the above stance, which does not mean that it does not suffer any harm.

\section{Introductory parts to the constitutions of the Visegrad Group countries: its meaning, legal relevance and way they reconstruct national and constitutional identity}

Constitutions of mentioned countries were passed in different periods. Slovakia and Czechia passed constitutions much earlier than Poland and Hungary. Republic of Poland sustained works on the new constitution about five years, during which governmental composition was significantly changing. ${ }^{38}$ Without any doubts, it influenced whole act - reflecting

34 BAŁABAN, 42.

35 ORGAD, 722-726.

36 MAŚNICKI, Jędrzej - STAWECKI, Tomasz: Wykładnia i stosowanie konstytucji w aktach prawnych państw Europy Środkowej i Wschodniej [Interpretation and application of Constitution in legal acts of the Countries of Central and Eastern Europe], in: Wykładnia konstytucji. Inspiracje, teorie, argumenty [Interpretation of the Constitution. Inspirations, theory, arguments], STAWECKI, Tomasz - WINCZOREK, Jan (eds.), Warszawa [Warsaw] 2014, 130-158.

37 Ibidem, 140-145.

38 Starting from 7 September 1992 (date of establishment of Constitutional Commission of National Assembly) until 17 October 1997 (which is the date, new Constitution on 2 April 1997 came into force). 
on the content of the preamble. Situation in Hungary is though completely different, as Fundamental Law of Hungary is one of the youngest constitution in whole EU. Thus, preambles will be presented chronologically, as the content of the introductory parts.

\section{Introduction to the Constitution on 1 September 1992 of the Slovak Republic ${ }^{39}$}

Polish doctrine specifies the above introduction laconically, stating that it has the nature of justification. ${ }^{40}$ In the initial passages, the preamble indicates the Sovereign which is made the Slovak Nation. Slovak doctrine, however, differs the notion of the Nation in the ethnic meaning (included in the preamble) and the Sovereign - the author of the constitution, which are citizens. ${ }^{41}$ It further includes a reference to past years, although the vision of the past "is quite vague", where the vision of the state and its history gave way rather to the will of conciliation and the effectiveness of enacting a new constitution. ${ }^{42}$ It does not refer directly to human dignity, although it guarantees the freedom of life and development. Preamble emphasizes the right to self-determination of nations, including connection with citizens of the state belonging to national minorities and ethnic groups. It also includes a clause on international integration expressing hope for "lasting and peaceful cooperation with other democratic states". This has the dimension of both coexistence (regarding relations with other states) as well as conciliation (in the form of a call for unity between a nation and members of national minorities). It can also be assumed that preamble proclaims the features of national identity, among which it indicates: "peaceful coexistence and cooperation both inside and outside the state, democracy, freedom, spiritual culture and economic prosperity". ${ }^{43}$ It also does not explicitly express the idea of human dignity, at most referring to it by conclusion. In the preamble the assumptions typical for the principle of subsidiarity can be seen - also not explicitly named in the introduction.

Slovak literature rarely refers to the introduction and its meaning. The exception here is $T$. Lalík, who first of all indicates the interpretative value of the introduction to the Constitution of the Slovak Republic. ${ }^{44}$ This is in line with the position of Slovak commentators quoted

39 Constitution on 1 September of the Republic of Slovakia, "Zbierka zákonov Slovenskej republiky" no. 244 from 1998 as amended.

40 SARNECKI, Paweł: Systematyka konstytucji [Systematics of the Constitution], in: Charakter i struktura norm Konstytucji [Character and structure of the norms of the Constitution], TRZCIŃSKI, Janusz (ed.), Warszawa [Warsaw] 1997, 28.

41 L'ALÍK, Tomáš: Preambula k Ústave SR a jej význam [Preamble to the Constitution and its meaning], in: Ústava Slovenskej republiky 20 rokov v národnom a európskom pohlade, Bratislava 2012, 211-212. Authors own translation. Online: https://www.academia.edu/14583732/Preambula_k_\%C3\%9Astave_SR_a_jej_v\%C3\%BDznam. The reason for such situation may be the occurrence of many national minorities in Slovakia. The author even states that citizenship is, to some extent, a prerequisite for integration / becoming a Sovereign. It rightly notes, however, that this concerns the impact on the political and legal aspect. In the axiological aspect, in relation to the common relation to a specific heritage of history, the Nation is all in an ethnic sense. It results from the phrase used in the preamble of "We - Slovak Nation".

42 MŁYNARSKA-SOBACZEWSKA, 239.

43 L'ALÍK, 214.

44 Ibidem. 
there. However, the large reserve of the Slovak Constitutional Court, which referred to the preambles twice, is noticeable. In the first judgment (PI. 8/96), the Tribunal accepted the interpretative nature of the preamble, but without granting it "the value of independent legal significance." 45 In the second one (I. ÚS 30/99), referring to the preambles indirectly, stated that "they are not essential elements of any normative act and are not relevant for the assessment of its normative content". ${ }^{46}$ Assumption on interpretative role of the preamble shall be considered as correct. Even despite the fact that later judgment of Slovak Constitutional Court withdrew that standpoint. However, it happened in highly unusual case, which was focusing on the aspect of amnesty granted by the Slovak President. Whole issue was glowingly political and - in such aspect - focusing upon the preamble with its typical, generic ambiguity, could be considered controversial. ${ }^{47}$ Consequently, interpretative role of the introduction to the Constitution of the Slovak Republic, would better fit international standards and even regional tendencies.

Then, one thing more we need to consider is the national and constitutional identity, which occurs from the content of the preamble. Slovak Constitutional Court has partially abandoned formal way of understanding democracy and the rule of law, which means that each decision could be subject to constitutional review. ${ }^{48}$ Furthermore, principle of the rule of law (certainty of law, justice etc.) was somehow connected with ideological of neutrality. ${ }^{49}$ On 30 January 2019 Slovak Constitutional Court gave its ruling directly on constitutional identity. ${ }^{50}$ Fundamental for its content was a conclusion, that "material core of the Slovak constitution" rest on the democracy and the rule of law. Such assumption was though accompanied with the particularly unique right of the Constitutional Court to determine the core - in accordance to occurring changes. Maybe on that basis, Court by defining the constitutional identity included also clear division of powers and independence of the judiciary power. ${ }^{51}$

Recalling presented above conclusions of Lalík, national identity though focus on "peaceful coexistence and cooperation both inside and outside the state, democracy, freedom, spiritual culture and economic prosperity", which is obviously different from the concept of the identity established by the Constitutional Court. Certainly one aspect common (and the most important) for the Slovak identity is the principle of democracy - mainly in its material aspect. In Court's opinion Slovak Constitution can weight certain values, but always prior would be rule of law, legal certainty and proper division of powers. Those are unbreakable principles of the whole political and legal system of the Slovak Republic. Foreign researchers and EU bodies should also consider the preamble's concept of nation-

45 Decision of the Constitutional Court of the Slovak Republic, Ref. File No. I ÚS 8/96, of 30 January 1996.

46 Decision of the Constitutional Court of the Slovak Republic, Ref. File No. I ÚS 30/99, of 28 June 1999.

47 One of the aspect there was an amnesty (prerogative typical for the President of the Republic) granted by the Prime Minister in highly controversial cases (national referendum in May 1997 or kidnapping son of the President).

48 Decision of the Constitutional Court of the Slovak Republic, Ref. File No. PL. ÚS 7/2017, of 31 May 2017.

49 Decision of the Constitutional Court of the Slovak Republic, Ref. File No. PL. ÚS 12/01, of 4 December 2007. Mentioned judgment was issued in a crucial case on the right to abortion.

50 Decision of the Constitutional Court of the Slovak Republic, Ref. File No. PL. ÚS 21/2014, of 30 January 2019. Judgment concerned legality of certain process of amending the constitution.

51 Here it is noteworthy that 4 judges voted separately - mainly because of the conviction that Constitutional Tribunal in case ÚS 21/2014 has exceeded its competences. 
al identity, understood as peaceful cooperation, freedom, spiritual culture and economic prosperity. Especially in way it presents potential limits of EU actions in the domestic legal order of Slovakia.

\section{Introduction to the Constitution on 16 December 1992 and Char- ter of Fundamental Rights and Freedoms of the Czech Republic ${ }^{52}$}

Providing legal text with preamble is rare in Czech legislation. It occurs most often in a situation of passing new, fundamental in its content and structure, law - especially in conditions of certain legal discontinuance. ${ }^{53}$ Czech researchers argued that the preamble includes political, historical and social declarations. Hence they sometimes deprived it of its normative nature, excluding (precisely questioning) its integrity with respect to the whole text. ${ }^{54}$ This argument, however, can not stand, because there is no evidence that it is the expression of the dominant part of the representatives of the doctrine. The introduction to the Constitution of Czechia, was placed after the title, which in combination with the fact of creating it - at the same time and mode as the article part - determines its integrity with the entire act. Polish doctrine includes the statement that the introduction to the Constitution of the Czech Republic has a teleological nature. ${ }^{55}$

Introduction to the Czech Constitution retains typical characteristic - at least if we consider regional countries. It is written in a unique, lofty form, being in a form of an oath. Indicates the Sovereign (Citizens of the Czech Republic), which, however, is important for the heritage of post-communist states "praising the undeniable values of dignity and freedom" and the equality and freedom of Citizens. Also expresses the will to join the Czech Republic to the "family of European and world democracy." In addition, it makes reference to the need to protect "cultural, material and spiritual wealth." Most importantly, the preamble to the Constitution of the Czech Republic expresses the principle of the rule of law as crucial for the world of liberal democracies by saying "determined to follow the proven principles of the rule of law". Seemingly enigmatic definition of human rights on the basis of the introduction to the Constitution of the Czech Republic comes from the division into the Constitution and the Charter of Fundamental Rights. Charter refers to the commonly occurring human and democratic values, while underlining the self-governing traditions of Slovakia and the Czech Republic. An important part is also the reference to the experience of previous years.

Referring to the content of the analyzed preamble, it shall be stated that Czech Constitutional Court was numerously interpreting principle of the rule of law. In the judgment ÚS 50/04, Court set a limit for the transfer of powers of state bodies to the Community. ${ }^{56}$

52 Resolution of the Presidency of the National Council of Czech Republic on 16 December on announcing Charter of Fundamental Rights and Freedoms as part of constitutional order of Czech Republic. "Sbírka zákonů České republiky" 1993 no. 1 from 28 December 1992, 17-23 (further: Charter of Fundamental Rights and Freedoms).

53 KLíMA, Karel: Constitutional Law of the Czech Republic, Plzeň [Pilsen] 2008, 101.

54 KUDRNA, 22.

55 SARNECKI, 39.

56 Decision of the Constitutional Court of the Czech Republic, Pl. ÚS 50/04: Sugar quotas, of 8 March 2006. In this case Constitutional Court did not refer to preamble directly, however it granted rule of law - explicitly mentioned in the preamble. 
Mentioned limits could not, however, harm the principle of primacy of Community law fundamental to EU law. Court also concluded that the Czech Court in its interpretation can not disregard the principles of Community law, which partly motivated the potentially higher "standard of protection of fundamental rights" within the Community. Furthermore, in judgment ÚS 19/08 (so called "Treaty of Lisbon" case), Court, analyzing the compatibility of the Treaty of Lisbon with the Czech constitutional order, stated that the EU, by virtue of the treaty shaping its new subjectivity, largely implements values well-known to Czech Constitution and expressed explicitly in its preamble as well as the preamble to the Charter of Fundamental Rights and Freedoms. ${ }^{57}$ Thus it based on assumptions that values based on respect for human dignity and freedom stem from the essence of humanism and shape the Czech constitutional system. Court also found an explicit connection between the provisions of the article part of the Constitution of the Czech Republic and the Charter of Fundamental Rights and Freedoms - mainly Art. 1. It is noticed in the Polish doctrine that the verdict was inspired by the Polish jurisprudence of the Constitutional Tribunal - in case K 18/04. ${ }^{58}$ Paradoxically, researchers stated even that - according to the unclear legal nature of the Charter of Fundamental Rights EU - Czech internal system of human rights protection could be weakened. ${ }^{59}$ Relation towards European integration could be found in the judgment ÚS 66/04 regarding the European Arrest Warrant. ${ }^{60}$ On its basis, the Court concluded that there was a constitutional principle according to which the provisions of national law, including constitutional provisions, should be interpreted in accordance with the principles of European integration and cooperation between Community bodies and Member State authorities. Therefore, if there are several possible interpretations of the Constitution, including the Charter of Fundamental Rights and Freedoms, and only some of them allow the fulfillment of the Czech Republic's obligation resulting from its membership of the European Union, it is necessary to adopt such an interpretation. It is important, however, that the doctrine of mutual responsibility was expressed on the basis of the ruling, which states: If Czech citizens are beneficiaries of benefits related to their status as EU citizens, it is natural to accept a certain scope of responsibility appropriate to these benefits. At the same time, the starting point for reflections on this subject was for the Czech Constitutional Court the assumption that the EU countries enjoy an equal high level of values and mutual trust, "based on the principles of democracy and the rule of law."

This does not mean that the preamble has only been applied to matters concerning interstate relations. It is worth paying attention to the judgment ÚS 557/09.61 One of the more

57 Decision, of the Constitutional Court of the Czech Republic, PI. ÚS 19/08: Treaty of Lisbon I, of 26 November 2008. 58 WÓJTOWICZ, Krzysztof: Traktat akcesyjny: wyrok z dnia 11 maja 2005 - K 18/04 [Accesion treaty: Judgment on 11 May 2005 - K 18/04], in: Na straży państwa prawa. Trzydzieści lat orzecznictwa Trybunału Konstytucyjnego [Securing rule of law principle. Thirty years of jurisdiction of Polish Constitutional Tribunal], GARLICKI, Lech - DERLATKA, Marta - WIĄCEK, Marcin (eds.), Warszawa [Warsaw] 2016, 506-507.

59 See also: WITKOWSKA-CHRZCZONOWICZ, Katarzyna: Wyrok Sądu Konstytucyjnego z dnia 26 listopada 2008 r. w sprawie zgodności z porządkiem konstytucyjnym Republiki Czeskiej Traktatu z Lizbony, sygn. Pl. ÚS 19/08 [Judgment of the Constitutional Court on 26 November 2008 on the conformity of the Treaty of Lisbon with Czech constitutional order, sign. PI. US 19/08], in: Przegląd Sejmowy, 17, 2009, 2, 272-273. Author recalls the position of the Czech Senate, who even spoke about the risk of pressure on the internal system of values, but also on the institutions of the European Union on national systems.

60 Decision of the Constitutional Court of the Czech Republic, Pl. ÚS 66/04: European Arrest Warranty, of 3 May 2005. 61 Decision of the Constitutional Court of the Czech Republic, I. ÚS 557/09: Limitation of Legal Capacity, of 18 August 2009. 
important elements of the judicial argumentation was the content of the preamble. It has been said there that the human dignity so deeply rooted in the axiology of the whole constitution and expressed in the preamble (and specific articles), allows only the full use of the attributes of humanity, realizing oneself and expressing one's personality and needs. ${ }^{62}$ Hence, while reconstructing constitutional identity in Czech, it shall be emphasized it was focused on the principle of sovereignty. In this sense, Czech Constitutional Court presented similar standpoint as Polish Constitutional Tribunal and German Federal Tribunal. It is though based on the minimal standard of the protection of the fundamental principles. EU law is granted primacy as long as it guarantees higher or - at least - the same level of mentioned protection. Furthermore, Czech constitutional identity stresses out the reciprocity of such relation. Preamble contains also certain and explicit reference to the rule of law, which also shall be found fundamental. National identity, which we could derive from the content of the introduction to the Constitution of the Czech Republic is rather similar to that mentioned in Slovak Republic. However Czech identity, unlike the Slovakian, is more oriented on the discontinuance and expresses clear rejection of the communist period. In parallel, issue of European values and compliance of both (internal and external) legal systems is still on the fore. However, in Czech we could have observed an attitude oriented on particularity of values and its regional interpretation - typical for Poland and Hungary. ${ }^{63}$ Discussion on values always open a space for discussion concerning weighting the values, but it always demand at least minimal consensus. Thus, it could occur from the correct interpretation of national and constitutional identity, grasped in the content of the preamble.

\section{Introduction to the Constitution on 2 April 1997 of the Republic of Poland ${ }^{64}$}

The introduction consists of 229 words (or according to another characteristic: 23 lines) ${ }^{65}$ concerned in two complex sentences. ${ }^{66} \mathrm{It}$ is characterized by sublime style and emotionality. It contains a common reference in Central European countries to the period of change after 1989, by pointing to the regained possibility of sovereign and democratic determination on the fate of the Homeland. ${ }^{67}$ It defines the Sovereign, which the Nation - in the

62 The essence of this judgment was the determination of the legitimacy of limiting the legal capacity of the applicant. In its judgment, the court outlined the non-constitutional activities in which the applicant was treated objectively, preventing effective protection of his rights (for instance: it concerned the arbitrary limitation of the ability to independently conduct their affairs in connection with certain mental problems).

63 ŠVEJDAROVÁ, Sylva - BORSKÁ, Jana: The refugee crisis and "European values", paper presented on $3^{\text {rd }}$ International Multidisciplinary Scientific Conference on Social Science \& Arts, SGEM 2016, Vienna, 6-9 April 2016. 64 Constitution on 2 April 1997 of the Republic of Poland passed by National Council on 2 April 1997, (Dz. U. 1997 no 78 item 483 as amended), further: Constitution of Poland.

65 GARLICKI, Wstęp, 8.

66 STRZĘPEK, Kamil Andrzej: Znaczenie prawne wstępu do Konstytucji RP z 1997 r. [Legal meaning of the preamble of the Constitution of Poland of 1997], Warszawa [Warsaw] 2013, 67.

67 The preamble of the Constitution of the Czech Republic of 16 December 1992 contained the phrase "in the era of renewal of the independent Czech state" and on the basis of the Charter of Fundamental Rights and Freedoms of 16 December 1992, the well-known Polish doctrine reveals the "bitter experience" from times when human rights and fundamental freedoms were suppressed in our "homeland"; in the preamble of the Constitution of the Slovak Republic of 1 September 1992, it was taken to mean "a century of hundred years' experience of fighting for national existence and its own statehood"; The Fundamental Law of Hungary of 25 April 2011 in words of the National Faith Statement (which is in fact the preface to the Fundamental Law) is undoubtedly a 
political sense - is made. Nation shall be interpreted as the totality of citizens referred to in art. 4 par. 1 of the Constitution of the Republic of Poland of 2 April 1997. Among the universal values it proclaims truth, justice, goodness and beauty. At the same time, preamble expresses the awareness of the need to cooperate with all nations "for the benefit of the Human Family". Other, important constitutional values (having separate from the preamble normative meaning) are also mentioned in the introduction: freedom and justice, cooperation of authorities, social dialogue and the principle of subsidiarity, which is to strengthen the rights of citizens and their communities. There were also calls - included in the second sentence - to respect the "innate and inalienable dignity of man" and the right to freedom and solidarity with others.

In the Polish legal system, the introductory part to the constitution has a significant interpretative dimension, which does not mean its complete legal relevance. ${ }^{68}$ The dominant view concerns full legal significance of the preamble's content, but relating to individual, certain sentences, which usually concerns principles of the legal system. ${ }^{69}$ Only in special circumstances, legal meaning can be granted to descriptive fragments of the preamble. This is though exceptional and exceeds from the scope of below analysis. Thus we shall rather see preamble as a "bridge" between natural law and positivist law, application of which creates the opportunity to correctly interpret the Constitution. ${ }^{70}$

Polish doctrine of constitutional law, following the studies of legal philosophers, states that Polish Constitution includes catalogue of values of greater (than temporally legal) heritage due to their "timelessness". ${ }^{71}$ This confirms that the constitutions (and preambles of the Visegrad Group countries) express the axiology of values known to international doctrine and judicature. Among the most important preamble lists: dignity, truth, justice, goodness and beauty. The creators of the preamble themselves stressed that the source of Polish culture is, on the one hand, the Christian heritage of the Nation, but also the universal human values. However, they are known and rooted in the culture of Western Europe. ${ }^{72}$ Hence, seeking for the national and constitutional identity clauses, we need to determine fundamental decision of the Polish Constitutional Tribunal (hereinafter: CT) on

vanguard, because all the above argumentation presents in a very descriptive manner, hence we find there the statement "We do not recognize the communist constitution of 1949", "Our present freedom began with the revolution of 1956", "We confess that after the decades of the $20^{\text {th }}$ century leading to the moral crisis we have an irresistible need for spiritual and intellectual renewal."

68 See: SZMYT, Andrzej: Zakres i treść Konstytucji RP z 1997 r. [Scope and content of the Constitution of Poland from 1997], in: Zeszyty Prawnicze BAS, 36, 2012, 4, 230. Author states that the preamble is suitable for spontaneous use "in a very narrow range". In the author's opinion, it expresses the so-called historical, cultural, political and religious imponderables, but "acting and expressing the base on which the whole Constitution rests". E.g.: BANASZAK, Konstytucja ..., 3.

69 GARLICKI, Wstęp, 8. In the author's opinion, they should be used directly. Others should be interpreted in conjunction with the appropriate extend contained in other provisions of the Constitution. "Most often in this context attention is paid to the principle of subsidiarity expressed in the preamble, effective functioning of public authorities, and the principle of social dialogue."

70 PIOTROWSKI, Ryszard: The Importance of Preamble in Constitutional Court Jurisprudence, in: Acta Juridica Hungarica, 52, 2011, 1, 36.

71 PIECHOWIAK, Marek: Elementy prawnonaturalne w stosowaniu Konstytucji RP [Natural-Law Elements in Application of the Constitution of the Republic of Poland], in: Przegląd Sejmowy, 94, 2009, 5, 75.

72 We should rather mention values well-established in Europe and known for ages. Even Greek philosophers knew and described: truth, justice, goodness and beauty. They are wrongly identified with the Christian circle of values. The definition of values as universal is perceived in the category of tautology. 
"Lisbon Treaty". ${ }^{73}$ In early parts of the decision, Polish CT focused upon changing concept of sovereignty, which is inseparably connected with the process of European integration. Tribunal admitted, that - being a member state of the EU, each country somehow limits it sovereignty - which then was followed by conclusion that respecting primacy of the EU law order and implementation of its rights does not mean rejection of the priority of the internal legal order. Thus, while defining constitutional identity CT narrowed its content to the concept of "competences, which can not be shared with the European Union" and has to be exercised exclusively by the certain Member States. Such catalogue contended: duty to respect human dignity and constitutional order, principle of country's obedience, principle of democracy, rule of law, principle of social justice, principle of subsidiarity and duty to respect better realization of constitutional values and injunction of non shareable competences of executive power or competences to create other competences.

It is worth stressing also reflection on the position and legal relevance on the "international integration clause".${ }^{74}$ It operates in the rank of a principle based on a specific "co-use" of the preamble clause regarding the awareness of cooperation with all nations for the benefit of the Human Family and art. 9 of the Constitution of the Republic of Poland stating that "Rzeczpospolita adheres to its binding international law". The above-mentioned ruling results from the interpretation made by the Constitutional Tribunal, which stated that "assessment of compliance of international agreements with the principle of specificity of law" must take into account the specificity of the requirement of cooperation with all countries for the benefit of the Human Family. ${ }^{75}$ It creates a directive to conduct a "favorable" interpretation of international law, which takes into account its specificity. According that even the clause "opening the Polish State" to broadly understood international law is being mentioned. ${ }^{76}$ Mentioned sentences of the introductory part to the Constitution and article 9 of the Constitution were stated the basis for passing on competences "on some issues" in the mode of art. 90 of the Constitution of the Republic of Poland of 2 April 1997. However, this was a separate position, because most often the CT only referred to the passage "for the benefit of the Human Family" as a general directive for the functioning of state policy - for example in the judgment K 18/04 and Kpt 2/08. ${ }^{77}$ In the opinion of the doctrine, there were even standpoints that cooperation should be reduced to creating common international legislation. Therefore, it encourages action to guarantee the implementation of the values known to European legislation first locally and then all over the world (even within the UN). ${ }^{78}$

73 Decision of the Constitutional Court of Poland, K 32/09, of 24 November 2010.

74 Decision of the Constitutional Court of Poland, K 18/04, of 11 May 2005.

75 Decision of Constitutional Tribunal of Poland, SK 6/10, of 21 September 2011.

76 Decision of Constitutional Tribunal of Poland, $K 33 / 12$, of 26 June 2013. It is worth noting, however, the dissenting opinions to the judgment cited, in which the judges clearly indicate the limits of transfer of competences under Art. 90 of the Constitution of the Republic of Poland of 2 April 1997.

77 Decision of Constitutional Tribunal of Poland, Kpt 2/08, of 20 May 2009.

78 WÓJTOWICZ, Krzysztof: ...świadomi potrzeby współpracy..., Preambuła Konstytucji Rzeczypospolitej Polskiej [...concern of the need of cooperation..., Preamble of the Constitution of the Republic of Poland], Warszawa [Warsaw] 2009, 83-84. 
Particular attention should also be given to the principle of subsidiarity, which was implemented in the preamble to the Constitution of the Republic of Poland directly from EU law. ${ }^{79}$ The principle of subsidiarity is primarily "to strengthen the rights of citizens and their communities". As stated by the Constitutional Tribunal in one of its rulings, this principle plays the role of a constitutional directive "in defining the tasks and powers of public authorities and distributing tasks between them". ${ }^{80}$ Different ruling was given on the basis of judgement K 62/0881, where, referring to the principle of subsidiarity Constitutional Tribunal stated that, it "circles the direction of public authorities' desired by the legislator". Subsidiarity assumes active participation of the state, obliging it even to "take appropriate action". Among them, it is advisable to mention due diligence in the course of conducting the legislative procedure, which, in the opinion of the Tribunal, by refraining from launching the so-called participation instruments violates the principle of subsidiarity. ${ }^{82}$ In Polish legislation, it can be assumed that "the principle of subsidiarity is a social concept that only justifies or non justifies the actions taken". This would justify the CT's common admission that the specific actions "remain or do not comply with the principle of subsidiarity".

Preamble consists also principle of solidarity linked with art. 2 of the Constitution of the Republic of Poland (the rule of law), being itself the basis for the interpretation of the systemic changes. It was even stated that "solidarism proclaims the conformity and commonality of interests of all individuals and social groups within a given community, as well as the obligation to participate in burdens for society. It assumes a mutual understanding between individuals, social groups and the state." There is also a catalog of cases in which the substantive scope of the principle of solidarity coincides with the principle of subsidiarity. It allows for mending the situation of individual entities and then "supporting" their situation "in the light of constitutional values and the desired image of social relations" ${ }^{83}$ Polish constitutional identity is then partially open concept. On that basis, it would be justified to extend it on the principles mentioned exclusively in the introduction to the constitution. Both were already mentioned and those are: subsidiarity and solidarity with others. Thus, we shall recall next two principles: ensurement of diligence and efficiency in the work of public bodies and cooperation between the public powers. Its belonging to the constitutional identity is based on simple assumption, that if preambles to the constitutions are one of the main sources of national and constitutional identity, principles established exclusively in their content, should also be part of it. Certain level of openness on European and International integration, grasped in words of the preamble "aware of the need for cooperation with all countries for the good of the Human Family", also should be included in the analyzed concept. National identity is though mainly implemented in last sentence of the preamble. Being itself a specific "call upon those who will apply this Constitution

79 Below I refer to the principles creating constitutional identity and mentioned exclusively in the content of the preamble to the Polish Constitution.

80 Decision of Constitutional Tribunal of Poland, K 29/00, of 8 May 2002.

81 Decision of Constitutional Tribunal of Poland, SK 62/08, of 12 April 2011.

82 More: Decision of Constitutional Tribunal of Poland, K 31/06, of 3 November 2006; Decision of Constitutional Tribunal of Poland, K 37/06, of 8 April 2009.

83 Decision of Constitutional Tribunal of Poland, K 28/11, of 20 December 2012. See also: Decision of Constitutional Tribunal of Poland, P 25/06, of 6 February 2007. 
for the good of the third Republic" and concerning: respect to the inherent dignity of the person, his or her right to freedom, the obligation of solidarity with others, and respect for these principles as the unshakeable foundation of the Republic of Poland.

Eventually, it is worth stressing recent actions introduced by Polish Constitutional Tribunal, which were connected with vast political controversies. None of recent judgments refers plainly to constitutional identity, but it can not be excluded that in future - in strict connection with political circumstances - such judgment will be found necessary. Kind of recapturing notion of the national identity is judgment $\mathrm{K} 1 / 17 .{ }^{84}$ In this judgment CT stated that the possibility of primacy of so-called "cyclical gatherings" restricting the right to non-recurring gatherings falls within the above scope. The criteria for the recognition of an assembly as cyclical is: the identity of the organizer, the route and frequency of gatherings (at least 4 gatherings per year), "relevant past" (at least 3 years of meetings or at least a common manifestation of beliefs), aim - an important event related to history of Poland. It clearly presents national oriented identity and creates serious threat of subjective interpretation of the right to organize and participate in assembly - depending on the will of governing bodies. Interference in the European values and principles of freedom of assembly is obvious. However, Polish Constitutional Tribunal, considered legislator's activities proportionate. One of the factors of the ruling was increased procedural requirements related to the status of a cyclical gathering ${ }^{85}$ and laconic "new, previously unknown situations". It even appointed selectively the judgments of the European Courts and Tribunals, which in the circumstances of the case should be regarded as seeking precedents, confirming a controversial verdict. The verdict itself - despite its large volume - does not provide reasonable grounds for dividing the view of the Constitutional Tribunal. A priori assumption that gatherings notified in advance, which would take place in a place similar to the one in which "cyclical meetings" are held, was completely unfounded. ${ }^{86}$ It is also contrary to the need for a narrow interpretation of restrictions on the law of assemblies. Especially if we compare it with the clause used by Constitutional Tribunal in its justification, in which it made a clear reference to the clause of the preamble: "securing everything what is valuable from over one thousand history of the state". This part of the introduction to the constitution never before possesed any legal relevance. Thus, we can witness the process of recapturing at least the national identity, example of which is limited right to organize assemblies if they not proclaims profound aim significant from Polish historical or national perspective. Somehow it is breaching founds of constitutional identity established by CT in its judgment on 2010 - in the scope of mutual relation between Polish and European legal orders or minimal guarantees of human rights.

84 Decision of Constitutional Tribunal of Poland, Kp 1/17, of 16 March 2017.

85 The nature and subject of these assemblies (patriotic, praising the history of the state) were also not without influence for the Constitutional Tribunal. It is worth mentioning that in order to strengthen the interpretation held, the Constitutional Tribunal even referred to the descriptive parts of the preamble to the Constitution of the Republic of Poland of 2 April 1997 - concerning f.e. cultural heritage or historical experience, which thereby established legal validity.

86 See: separate votes of: Justice M. Pyziak - Szafnicka. 


\section{National Avowal to the Fundamental Law on 25 April 2011 of Hungary ${ }^{87}$}

The constitutional system of Hungary until 2011 was based on a prior act of constitutional rank, which was the Basic Law of 1949. Until then, a laconic introduction which emphasized the temporariness of the entire act was being used. ${ }^{88}$ However, the legislator did not avoid certain declarations by stating the adoption of the principle of rebuilding the state "into a legal state, implementing a multi-party system and a social market economy" is proclaimed. Situation has changed significantly, when new Fundamental Law on 2011 came into force. Hungary - perhaps due to the prolonged process of transition and political transformation - wanted to express its condemnation of the communist period. Even, the name of the introduction to the Fundamental Law, which is called the National Avowal, has been changed. Nevertheless, despite all unique qualities of the Fundamental Law of Hungary, it shall be emphasized it is relatively modern act, which implements vast catalogue of modern rights. ${ }^{89}$ In a sense, here lies different "spirit" of their Constitution, as an act passed and exercised more than 20 years after formal beginning of the transitional period in Central and Eastern Europe.

The structure of the introduction draws attention because it consists of 30 sentences. Following the other introductions to the constitutions of the countries of the region, it defines the Sovereign, who are the members of the Hungarian Nation, refers to human dignity, which is the "basis of human existence" and combining it with freedom, as well as makes (in the third paragraph) a clear historical reference. In addition, it includes new elements such as the principles of sustainable development and protection of future generations, the need to help weaker people and, consequently, to ensure prosperity, security, order, justice and freedom. It expresses many contemporary values: dignity, solidarity, equality, the need for international integration and environmental protection.

Simultaneously, National Avowal contents a lot of historical references. It is pointless to refer to it directly, thus I will present it subjectively. Those are: deeply rooted Christian heritage (and reference to Saint Stephen or "Christianity preserving Hungarian nationhood"), intellectual achievements and unique language, honour to the achievements of the historic constitution and protection of the identity rooted therein, strong and harsh disapproval of "suspension of Hungarian historic constitution due to foreign occupations" - especially during the communism period, which shall be found non - existing (by words on restoration of our country's self-determination, lost on the nineteenth day of March 1944, from the second day of May 1990, when the first freely elected organ of popular representation was formed). The scope of the reference to history, however, is perceived as high. Some see this as an earlier, inadequate resolution of past events taking place in Hungary, heightened by a sense of injustice, which in the $20^{\text {th }}$ met the Hungarian nation. ${ }^{90}$

87 Fundamental Law of Hungary on 25 April 2011, Konstytucje państw Unii Europejskiej, "Wydawnictwo Sejmowe", Warsaw 2011.

88 BORSKI, Maciej: Konstytucja nowych Węgier czy nowa Konstytucja Węgier? Próba analizy [The constitution of a new Hungary or the New Constitution of Hungary? Attempt of an analysis], in: Przegląd Prawa Publicznego, 2013, 4, 20.

89 Ibidem, 36. Among them Hungarians indicate: effective implementation of the EU Charter of Fundamental Rights and environmental protection regulations, sustainable economy and guarantees not to allow excessive indebtedness of the state.

90 Ibidem, 20-21. 
Introductory parts to the legal acts, were commonly used and accepted in Hungary - mainly due to their interpretative function. ${ }^{91}$ Their history could start from $13^{\text {th }}$ century, with its main role played in $20^{\text {th }}$ century. Therefore, on the limited content of below article, I focus on legal relevance of the National Avowal and - partially - relevance of former, transitional preamble. It proclaimed the adoption of the principle of rebuilding the state into a "legal state, implementing a multi-party system and a social market economy". This is an expression of the rules known to European law. In addition, it was lined with the interpretation of the Hungarian Constitutional Court, which clearly defined the preamble as the basis for the introduction of "the rule of parliamentary democracy" (judgment 15/2007) as well as the free market economy (judgment 19/2009). The previous preamble was then used as a justification for the changes in the political system. ${ }^{92}$ It does not mean it had clear legal relevance. ${ }^{93}$ Hungarian researchers, express a lot of skepticism about its phenomenon, stressing that such an editorial favored judge activism. This has reduced citizens' trust in the existing legal system, which was often based on a extensive interpretation of the law. ${ }^{94}$ It was also connected with an issue of - known to Hungarian doctrine of law - legalism and attachment to strictly linguistic interpretation of law. ${ }^{95}$

Situation has changed with implementing new Fundamental Law and its introduction - National Avowal. It was possible to assume that by creating a new constitution the Hungarian constitutional legislator would decide to take into account the introductory part - as for example in other countries of the region. Following legal considerations, it should be stressed that in accordance with art. R para 3, National Avowal should form the basis for the interpretation of the Fundamental Law and its aims (among which, first and foremost, it should refer to "the historical part of the constitution"). In its light the attitude to the communist period is highly negative. The judgment of the Hungarian Constitutional Tribunal, ref. No. $45 / 2012^{96}$ is an example of such attitude. The subject of this judgment was the assessment of compliance with the Fundamental Law for changes introduced in the period of subsequent amendments, by comparing them with the current legal status. It has been stated that many articles and even the preamble to Constitution on 1989 violated the principle of legal certainty. The provisions of the new introduction are quoted as expressing the principle that the new Fundamental Law establishes the foundations of the legal order.

91 TRÓCSÁNYI, László: Wokół prac nad Ustawą Zasadniczą Węgier. Tożsamość konstytucyjna a integracja europejska [Among works on the Hungarian Fundamental Law. Constitutional Identity towards European integration], Warszawa [Warsaw] 2017, 41-49.

92 Decision of the Constitutional Court of Hungary, 19/2009, of 25 February 2009. Where reference is made to the preamble as guaranteeing the introduction of free market mechanisms - then still in the Republic of Hungary. See also: Decision of the Constitutional Court of Hungary, 15/2007, of 9 March 2007. When Constitutional Tribunal established preamble "as the basis to implement" parliamentary democracy; online: http://public.mkab.hu/ dev/dontesek.nsf/O/DA9E7BA92F85F868C1258382003F5D3B?OpenDocument\&english.

93 See: TRÓCSÁNYI, 47. And judgments presented there.

94 See: LUPO, Nicola: What Hungarian Constitutional Experience Can Teach European Constitutionalism, in: Challenges and pitfalls in the recent Hungarian constitutional development. Discussing the New Fundamental Law of Hungary, SZENTE, Zoltán - MANDÁK, Fanni - FEJES, Zsuzsanna (eds.), Paris 2015, 114-129.

95 FEKETE, Balázs: The National Awoval: More than a Conventional Preamble to a Constitution, in: Challenges and pitfalls in the recent Hungarian constitutional development. Discussing the New Fundamental Law of Hungary, SZENTE, Zoltán - MANDẢK, Fanni - FEJES, Zsuzsanna (eds.), Paris 2015, 11-12.

96 Decision of the Constitutional Court of Hungary, 45/2012, of 29 December 2012. 
Nevertheless, National Avowal appeared rarely in the case-law of the Constitutional Tribunal of Hungary. ${ }^{97}$ National Avowal opens legal discourse on the content of the "historical constitution of Hungary", but still has to be interpreted cautiously. ${ }^{98}$ Furthermore its extensive interpretation shall be considered as faulty.

Crucial remarks on that stems from the decision of the Hungarian Constitutional Court on 5 December $2016 .{ }^{99}$ On its basis, constitutional identity of Hungary was defined. Constitutional Court established two limits for conferred or jointly exercised competences: sovereignty review and identity review. First was basing on assumption the exercise of power (within the EU) may not result in the loss of the ultimate oversight possibility of the people over the public power recognized by the Fundamental Law. Second creates a catalogue of principles, which creates the identity. Interestingly mentioned catalogue meant to be open including f.e. freedoms, division of power, republican form of state, respect of public law autonomies, freedom of religion, legality, parliamentarism, equality before the la, recognition of judicial power, protection of nationalities that are living in Hungary. Furthermore, constitutional identity was extended also on the areas "shaping citizens' living conditions" - among which pointing: areas in which linguistic, historical and cultural involvement of Hungary can be detectable. Factors important in detecting the constitutional identity are also content of the article R.3 of the Fundamental Law, National Avowal and historical constitutions they refer to. Such broadened interpretation on the constitutional identity, equals it with the national identity - being itself a tremendous material for analysis.

\section{European Constitutional Identity in relation towards constitutional preambles of V4 countries and identity they create}

In the course of changes after 1989 related to the democratization process of Central European countries, these countries undertook tedious efforts to join existing and emerging international structures. As shown above, this was reflected even in the introduction to their constitutions. This process involved a change in legislation, compliance with international obligations and, above all, acceptance of the foundations of the axiology of European principles and values. As a result, they have become an immanent part of the legal system. Principle of a judicial interpretation of favorable European law - has intensified this process. However, one should consider how - basing on the introductory parts to the constitutions of these countries - the principles and values were implemented. It is worth referring to the notion of "shared values" mentioned in the preamble of the Charter of Fundamental Rights, which should be shared between countries for a peaceful future. ${ }^{100}$ Among these, one should indicate "inviolable and inalienable human rights as well as freedom, democracy, equality and the rule of law." It is impossible not to refer to art. 2 TEU, on the basis of which "the Union is founded on the values of respect for human dignity, freedom, democracy, equality, the rule of law and respect for human rights, including the rights of

97 Conclusion concerns only judgements translated into English.

98 TRÓCSÁNYI, 51-52.

99 Decision of the Constitutional Court of Hungary, 22/2016, of 5 December 2016.

100 WRÓBEL, Andrzej: Karta Praw Podstawowych Unii Europejskie. Komentarz [Charter of Fundamental Rights of the European Union. Commentary], Warszawa [Warsaw] 2013, 15. 
persons belonging to minorities." Its meaning is complied with the preamble to the TEU, where main focus is paid to the principle of democracy - mentioned to be source of inspiration among "universal values of the inviolable and inalienable rights of human person, freedom, equality and the rule of law". In the TEU preamble all of the signatories to the Treaty, confirm their "attachment to the principles of democracy", which is also "desired to enhance democratic and efficient functioning of the institutions". Values shall be shared by the Member States in a society "based on pluralism, non-discrimination, tolerance, justice, solidarity and equality between women and men". The above can be achieved by deepening the international integration process, which is associated with the concept of the socalled "European identity." However, it is limited by the EU's obligation to protect national identity (defined in Article 4 passage 2 TEU). ${ }^{101}$ Maintaining proper relation is though difficult. It is indicated that a uniform understanding of values and principles such as freedom, proportionality and dignity in all 28 EU Member States is practically impossible and thus generating interpretational conflicts. ${ }^{102}$ One of the ways of their elimination may be a kind of interpretation of "preferences" proposed by experts in European law. It should rely on appropriate selection of methods and means of interpretation depending on the situation. According to this theory, when it will be better to stick to the characteristic doctrine of a given state, it should be used. The same applies to the interpretation of principles and values developed in case law and international doctrine. ${ }^{103}$ However, this requires a kind of openness to international law and treating it as a "friend" and not an "enemy".

Indicating common European values is one thing, other is taking an attempt to define European Constitutional Identity. Specialists on the EU law list them in five categories, which aims to present what is contained in European law heritage. ${ }^{104}$ First of all is the "fundamental role of the reason in public life", which means the society (and ruling bodies) shall arrange its activities among aims, which is found - at least by the majority - as fair and right. Hence so important is the unity of values among the EU member states. ${ }^{105}$ Second is the concept of individual liberty, which is simply a freedom of one entity, ending were began freedom of others. Third, but not less important is toleration of other and not using towards others any kind of moral or factual disapproval - especially concerning language, religion, culture, conceptions of life. Fourth and also fundamental is protection of the democracy principle, founded on unshakeable right of the majority to rule, which though respects rights of the minorities. ${ }^{106}$ Common identity need further exercising, basing mainly on:

\section{Ibidem, 16.}

102 KAMIŃSKI, Ireneusz Cezary: Karta Praw Podstawowych jako połączenie praw i zasad - strukturalna wada czy szansa? [Charter of Fundamental Rights as a combination of laws and principles - structural defect or a chance?], in: Karta Praw Podstawowych w europejskim i krajowym porządku prawnym [Charter of Fundamental Rights ...], WRÓBEL, Andrzej (ed.), Warszawa [Warsaw] 2009, 38.

103 KONCEWICZ, Tomasz Tadeusz - WARYLESKA, Katarzyna: Przemyśleć Europę i jej prawo dzisiaj, to zadać właściwe pytania... [Re-thinking Europe and its today's right, is to form a proper questions...], in: Ochrona praw Obywatelek i Obywateli Unii Europejskiej [Protection of rights of the Citizens of the European Union], BARANOWSKA, Grażyna - BODNAR, Adam - GILSZCZYŃSKA-GRABIAS, Aleksandra (eds.), Warszawa [Warsaw] 2015, 97.

104 SADURSKI, Wojciech: European Constitutional Identity?, Florence 2006, 1-22.

105 Ibidem, 9-10.

106 Ibidem, 11-13. Having significant experience on the common law, presented author stresses also difference between European identity and American Identity. It is: positive functions of the State (in European context), which is securing citizens and their social rights, methods of protecting democracy against anti-democratic views (also in favour of European attitude). 
protection of the core of human rights, the stabilization of normative expectations as well as connection to the values, interests and convictions of those affected. ${ }^{107}$

On that basis, we shall indicate each of the analyzed preambles to the constitutions of the Visegrad countries, proclaims European Constitutional Identity offishly. Even if we consider solemn expression on democracy, individual liberty and - partially - specific roles played by the State, as an example of proclamation of European Constitutional Identity, other parts are not sufficiently answering its content. However, it stems from typical roles played by the preambles. As it was already presented introductory parts to the constitutions plays integrative roles, building internal community. European context - in the preambles - is rather reserved - usually grasped in one sentence. Thus open and controversial is arising subject of potential "Hungarian abuse of constitutional identity", which is in fact national constitutional pariochalism. ${ }^{108}$ Recently it is emphasized that constitutional pluralism - and notion of constitutional identity, resulting from it - "invites a legal chaos in which national courts could [...] pick and choose which EU laws their states need to follow and which they do not". ${ }^{109}$ Some remarks were made on the basis of National Avowal, which ambiguity was also considered a "serious threat to democracy". Potentially this could lead to a progressive separation of internal rights and their interpretation and EU law. ${ }^{110}$ But, it is not certain on what basis authors makes above assumption. Fact that just after entering EU, Hungarian Constitutional Court presented open and sufficient level of "openness" on the EU legal order, does not mean in parallel, that now Hungary has abandoned its constitutional identity. Especially while Hungary passed completely new Fundamental Law on 2011. Situation of abandoning recent identity, could have rather occurred in the Republic of Poland, whereas Constitutional Tribunal changed way of its interpretation without changing act in general.

\section{Conclusion}

Countries of the Visegrad group share similar experiences connected with the process of entering the EU. It happened in the same time and circumstances - on 1 May 2004. They also faced the same difficulties and presented similar approach in implementing Western legal standards - defined as common European heritage or "unity of values". Even preambles of mentioned countries, in the scope of the content and established values, are significantly similar. Furthermore, way of reconstruction the national and constitutional identity points same principles - with certain differences concerning Hungary. Rulings of the Constitutional Courts of Poland, Czechia and Slovakia was focusing on the procedural aspect of sovereignty. However, it maintained certain level of minimum "openness" on the EU legal system. EU law was found prior as long as it guarantees at least the same security for basic laws important from the State's perspective. Identity was also perceived

107 VON BOGDANDY, Armin: Common Principles for a Plurality of Orders: A Study on Public Authority in the European Legal Area, in: Jean Monnet Working Papers Series, 2014, 16, 41-42.

108 HALMAI, Gábor: Abuse of Constitutional Identity. The Hungarian Constitutional Court on Interpretation of article E) (2) of the Fundamental Law, in: Review of Central and East European Law, 43, 2018, 1, 41-42.

109 KELEMEN, Daniel R. - PECH, Laurent: Why autocrats love constitutional identity and constitutional pluralism. Lesson from Hungary and Poland, Leuven 2018, 8.

110 KELEMEN, Katalin: The New Hungarian Constitution: Legal Critiques from Europe, in: Review of Central and Eastern European Law, 42, 2017, 1, 7-8. 
from the scope of the minimal procedural requirements of democratic country - basic on rule of law, respecting proper division of powers and independence of judiciary power. In this sense it complied with doctrinal way of defining European Constitutional Identity and proclaimed reservation of particular principles to be exclusively exercised by the State. Preambles played important role in that process, f.e. by expressing need to co-operate with other countries or expressing explicit respect to principles and values known Western democracies. Other attitude characterized Hungary, where Constitutional Court focused upon material aspect of identity. Main assumption was, that Hungarian constitutional system will last until Constitutional Court will defend state's sovereignty, historical constitution and national identity. Thus, it presented EU legal order not as complying, but competing Hungarian legal order. To make it more complex, it shall be added, that ruling on constitutional identity in Hungary was made in case of "asylum seekers". Hence it shall be emphasized preambles to the constitutions of Visegrad countries secures mainly national and constitutional identity. Aspect they relates to the European Constitutional Identity is reserved and occurs only in the proclamation of plain respect for democracy.

\section{References}

\section{Court decisions}

\section{Constitutional Court of Hungary}

- Decision of the Constitutional Court of Hungary, 15/2007, of 9 March 2007

- Decision of the Constitutional Court of Hungary, 19/2009, of 25 February 2009

- Decision of the Constitutional Court of Hungary, 45/2012, of 29 December 2012

- Decision of the Constitutional Court of Hungary, 22/2016, of 5 December 2016

\section{Constitutional Court of the Czech Republic}

- Decision of the Constitutional Court of the Czech Republic, Pl. ÚS 66/04: European Arrest Warranty, of 3 May 2005

- Decision of the Constitutional Court of the Czech Republic, PI. ÚS 50/04: Sugar quotas, of 8 March 2006

- Decision, of the Constitutional Court of the Czech Republic, Pl. ÚS 19/08: Treaty of Lisbon I, of 26 November 2008

- Decision of the Constitutional Court of the Czech Republic, I. ÚS 557/09: Limitation of Legal Capacity, of 18 August 2009

\section{Constitutional Court of the Slovak Republic}

- Decision of the Constitutional Court of the Slovak Republic, Ref. File No. I ÚS 8/96, of 30 January 1996

- Decision of the Constitutional Court of the Slovak Republic, Ref. File No. I ÚS 30/99, of 28 June 1999

- Decision of the Constitutional Court of the Slovak Republic, Ref. File No. PL. ÚS 12/01, of 4 December 2007

- Decision of the Constitutional Court of the Slovak Republic, Ref. File No. PL. ÚS 7/2017, of 31 May 2017

- Decision of the Constitutional Court of the Slovak Republic, Ref. File No. PL. ÚS 21/2014, of 30 January 2019 


\section{Constitutional Tribunal of the Republic of Poland}

- Decision of Constitutional Tribunal of Poland, K 29/00, of 8 May 2002

- Decision of the Constitutional Court of Poland, K 18/04, of 11 May 2005

- Decision of Constitutional Tribunal of Poland, K 31/06, of 3 November 2006

- Decision of Constitutional Tribunal of Poland, P 25/06, of 6 February 2007

- Decision of Constitutional Tribunal of Poland, K 37/06, of 8 April 2009

- Decision of Constitutional Tribunal of Poland, Kpt 2/08, of 20 May 2009

- Decision of the Constitutional Court of Poland, K 32/09, of 24 November 2010

- Decision of Constitutional Tribunal of Poland, SK 62/08, of 12 April 2011

- Decision of Constitutional Tribunal of Poland, SK 6/10, of 21 September 2011

- Decision of Constitutional Tribunal of Poland, K 28/11, of 20 December 2012

- Decision of Constitutional Tribunal of Poland, K 33/12, of 26 June 2013

- Decision of Constitutional Tribunal of Poland, Kp 1/17, of 16 March 2017

BAŁABAN, Andrzej: Polskie problemy ustrojowe. Konstytucja, źródła prawa, samorząd terytorialny, prawa człowieka [Polish political system dilemmas. Constitution, sources of law, local government, human rights], Kraków [Cracow] 2003.

BANASZAK, Bogusław: Konstytucja Rzeczypospolitej Polskiej. Komentarz [Constitution of the Republic of Poland. Commentary], Warszawa [Warsaw] 2012, 4.

BANASZAK, Bogusław: Limitation of Sovereignty by the European Integration - The Polish Approach, in: lus Gentium: Comparative Perspectives on Law and Justice, Dordrecht 2016, 102.

BARTOLE, Sergio: Comparative Constitutional Law - an Indispensable Tool for the Creation of Transnational Law, in: European Constitutional Law Review, 13, 2017, 4, 601-602.

BISZTYGA, Andrzej: Zmiana Konstytucji jako źródła prawa o najwyższej mocy prawnej [Changing the Constitution as the act of highest legal power], in: Zmena Práva, BÁRÁNY, Eduard (ed.), Bratislava 2013, 90.

BORSKI, Maciej: Konstytucja nowych Węgier czy nowa Konstytucja Węgier? Próba analizy [The constitution of a new Hungary or the New Constitution of Hungary? Attempt of an analysis], in: Przegląd Prawa Publicznego, 2013, 4, 20-21, 36.

CLOOTS, Elke: National Identity, Constitutional Identity, and Sovereignty in the EU, in: Netherland Journal of Legal Philosophy, 45, 2016, 2, 82-84.

DAVIS, Charles Hall: Preamble to Constitution of the League of Nations, in: Virginia Law Register, 5, 1919, 1, 16.

DE CRUZ, Peter: Comparative law in a Changing World, New York 2007.

ERIKSEN, Svein: Institution building in Central and Eastern Europe: Foreign Influences and Domestic Responses, in: Review of Central and East European Law, 32, 2007, 3, 333-334. FEKETE, Balázs: The National Awoval: More than a Conventional Preamble to a Constitution, in: Challenges and pitfalls in the recent Hungarian constitutional development. Discussing the New Fundamental Law of Hungary, SZENTE, Zoltán MANDÁK, Fanni - FEJES, Zsuzsanna (eds.), Paris 2015, 11-12.

GARLICKI, Lech: Constitutional Law, in: Introduction to Polish Law, FRANKOWSKI, Stanisław (ed.), Hague 2005, 5-8.

GARLICKI, Lech: Wstęp [Introduction], in: Konstytucja Rzeczypospolitej Polskiej. Komentarz. Tom V [Constitution of the Republic of Poland. Commentary. Vol. V], GARLICKI, Lech (ed.), Warszawa [Warsaw] 2007, 2. 
GARLICKI, Lech: Constitutional Court of Poland 1982-2009, in: The political origins of Constitutional Courts. Italy, Germany, France, Poland, Canada, United Kingdom, PASQUINO, Pascquale - BILLI, Francesca (eds.), Rome 2009, 30.

GWIŻDŻ, Andrzej: Wstęp do Konstytucji - zagadnienia prawne [Introduction to the Constitution - legal aspects], in: Charakter i struktura norm Konstytucji [Character and structure of the norms of the Constitution], TRZCIŃSKI, Janusz (ed.), Warszawa [Warsaw] 1997, 169, 173.

HALMAI, Gábor: Abuse of Constitutional Identity. The Hungarian Constitutional Court on Interpretation of article E) (2) of the Fundamental Law, in: Review of Central and East European Law, 43, 2018, 1, 41-42.

JOWEL, Jeffrey: The Venice Commission: disseminating democracy through law, in: Public Law, 2001, 675-676.

KAMIŃSKI, Antoni - KAMIŃSKI, Bartłomiej: Inżynieria konstytucyjna w postkomunistycznych przemianach ustrojowych [Constitutional engineering in post communism political chages], in: Ruch prawniczy, ekonomiczny i socjologiczny, 78, 2016, 2, 251.

KAMIŃSKI, Ireneusz Cezary: Karta Praw Podstawowych jako połączenie praw i zasad strukturalna wada czy szansa? [Charter of Fundamental Rights as a combination of laws and principles - structural defect or a chance?], in: Karta Praw Podstawowych w europejskim i krajowym porządku prawnym [Charter of Fundamental Rights ...], WRÓBEL, Andrzej (ed.), Warszawa [Warsaw] 2009, 38.

KELEMEN, Daniel R. - PECH, Laurent: Why autocrats love constitutional identity and constitutional pluralism. Lesson from Hungary and Poland, Leuven 2018.

KELEMEN, Katalin: The New Hungarian Constitution: Legal Critiques from Europe, in: Review of Central and Eastern European Law, 42, 2017, 1, 7-8.

KINANDER, Morten: Comparing Courts: The Accountability Function of the Constitutional Courts of Poland and Hungary, in: Review of Central and East European Law, 39, 2014, 2, 150, 153.

KLÍMA, Karel: Constitutional Law of the Czech Republic, Plzeň [Pilsen] 2008.

KONCEWICZ, Tomasz Tadeusz - WARYLESKA, Katarzyna: Przemyśleć Europę i jej prawo dzisiaj, to zadać właściwe pytania... [Re-thinking Europe and its today's right, is to form a proper questions...], in: Ochrona praw Obywatelek i Obywateli Unii Europejskiej [Protection of rights of the Citizens of the European Union], BARANOWSKA, Grażyna BODNAR, Adam - GILSZCZYŃSKA-GRABIAS, Aleksandra (eds.), Warszawa [Warsaw] 2015, 97.

KUBAS, Sebastian: Dynamika procesu demokratyzacji Węgier. Próba określenia zjawiska $w$ teorii [Dynamic of the democratisation process in Hungary. Assignement in theory], in: 25 lat transformacji w krajach Europy Środkowej i Wschodniej, BARAŃSKI, Marek WIŚNIEWSKI, Jerzy (eds.), Katowice 2014, 89, 92-95.

KUDRNA, Jan: Two Preambles in the Czech Constitutional System, in: Acta Juridica Hungarica, 52, 2011, 1, 22, 24.

LUPO, Nicola: What Hungarian Constitutional Experience Can Teach European Constitutionalism, in: Challenges and pitfalls in the recent Hungarian constitutional development. Discussing the New Fundamental Law of Hungary, SZENTE, Zoltán MANDÁK, Fanni - FEJES, Zsuzsanna (eds.), Paris 2015, 114-129.

L'ALÍK, Tomáš: Preambula k Ústave SR a jej význam [Preamble to the Constitution and its meaning], in: Ústava Slovenskej republiky 20 rokov v národnom a európskom pohlade, Bratislava 2012, 211-212, 214. 
MADEJA, Andrzej: Komparatystyka konstytucyjnoprawna. Antecedencje, ewolucja, przewidywanie kierunku rozwoju [Comparative Constitutional Law. Origins, Evolutions, Possible Development], in: Studia luridica Toruniensia, 6, 2010, 134-141.

MAŚNICKI, Jędrzej - STAWECKI, Tomasz: Wykładnia i stosowanie konstytucji w aktach prawnych państw Europy Środkowej i Wschodniej [Interpretation and application of Constitution in legal acts of the Countries of Central and Eastern Europe], in: Wykładnia konstytucji. Inspiracje, teorie, argumenty [Interpretation of the Constitution. Inspirations, theory, arguments], STAWECKI, Tomasz - WINCZOREK, Jan (eds.), Warszawa [Warsaw] 2014, 130-158.

ORGAD, Liav: The preamble in constitutional interpretation, in: International Journal of Constitutional Law, 8, 2010, 4, 716-718, 722-726, 731.

PIECHOWIAK, Marek: Elementy prawnonaturalne w stosowaniu Konstytucji RP [Natural-Law Elements in Application of the Constitution of the Republic of Poland], in: Przegląd Sejmowy, 94, 2009, 5, 75.

PIOTROWSKI, Ryszard: The Importance of Preamble in Constitutional Court Jurisprudence, in: Acta Juridica Hungarica, 52, 2011, 1, 36.

SADURSKI, Wojciech: European Constitutional Identity?, Florence 2006.

SARNECKI, Paweł: Systematyka konstytucji [Systematics of the Constitution], in: Charakter i struktura norm Konstytucji [Character and structure of the norms of the Constitution], TRZCIŃSKI, Janusz (ed.), Warszawa [Warsaw] 1997, 28, 39.

STRZĘPEK, Kamil Andrzej: Znaczenie prawne wstępu do Konstytucji RP z 1997 r. [Legal meaning of the preamble of the Constitution of Poland of 1997], Warszawa [Warsaw] 2013.

SZMYT, Andrzej: Zakres i treść Konstytucji RP z 1997 r. [The scope and content of the Constitution of the Republic of Poland of 1997], in: Zeszyty Prawnicze BAS, 36, 2012, 4, 230.

ŠVEJDAROVÁ, Sylva - BORSKÁ, Jana: The refugee crisis and "European values", paper presented on $3^{\text {rd }}$ International Multidisciplinary Scientific Conference on Social Science \& Arts, SGEM 2016, Vienna, 6-9 April 2016.

TATHAM, Allan: Central European Constitutional Courts in the Face of EU Membership. The influence on the German model in Hungary and Poland, Leiden 2013.

TRÓCSÁNYI, László: Wokół prac nad Ustawą Zasadniczą Węgier. Tożsamość konstytucyjna a integracja europejska [Among works on the Hungarian Fundamental Law. Constitutional Identity towards European integration], Warszawa [Warsaw] 2017.

VON BOGDANDY, Armin: Common Principles for a Plurality of Orders: A Study on Public Authority in the European Legal Area, in: Jean Monnet Working Papers Series, 2014, 16, 41-42.

WITKOWSKA-CHRZCZONOWICZ, Katarzyna: Wyrok Sądu Konstytucyjnego z dnia 26 listopada 2008 r. w sprawie zgodności z porządkiem konstytucyjnym Republiki Czeskiej Traktatu z Lizbony, sygn. Pl. ÚS 19/08 [Judgment of the Constitutional Court on 26 November 2008 on the conformity of the Treaty of Lisbon with Czech constitutional order, sign. PI. US 19/08], in: Przegląd Sejmowy, 17, 2009, 2, 272-273.

WÓJTOWICZ, Krzysztof: ...świadomi potrzeby współpracy..., Preambuła Konstytucji Rzeczypospolitej Polskiej [...concern of the need of cooperation..., Preamble of the Constitution of the Republic of Poland], Warszawa [Warsaw] 2009, 83-84. 
WÓJTOWICZ, Krzysztof: Traktat akcesyjny: wyrok z dnia 11 maja 2005 - K 18/04 [Accesion treaty: Judgment on 11 May 2005 - K 18/04], in: Na straży państwa prawa. Trzydzieści lat orzecznictwa Trybunału Konstytucyjnego [Securing rule of law principle. Thirty years of jurisdiction of Polish Constitutional Tribunal], GARLICKI, Lech - DERLATKA, Marta - WIĄCEK, Marcin (eds.), Warszawa [Warsaw] 2016, 506-507.

WRÓBEL, Andrzej: Karta Praw Podstawowych Unii Europejskie. Komentarz [Charter of Fundamental Rights of the European Union. Commentary], Warszawa [Warsaw] 2013.

\section{Author}

Mgr. Karol Popławski

Akademia Leona Koźmińskiego

Kozmiski University

ul. Jagiellońska 57/59, 03-301 Warszawa, Poland

poplawski_karol@interia.pl 